\title{
EHMTI-0349. Levetiracetam in the treatment of pediatric headache
}

\author{
T Rizk \\ From 4th European Headache and Migraine Trust International Congress: EHMTIC 2014 \\ Copenhagen, Denmark. 18-21 September 2014
}

\section{Introduction}

Migraine headache is common among the pediatric and adolescent population, with prevalence rates ranging from approximately

$3 \%$ to $4 \%$ in early ages to as high as $8 \%$ to $23 \%$ during adolescence. Before puberty, boys have more headaches than girls, but after puberty, migraine headaches occur more frequently in girls. Recent studies have highlighted the potential use of levetiracetam in pediatric migraine prophylaxis, it resulted in significant decreases in mean headache frequency were observed at dosages similar to those used in epilepsy patients, with good tolerability.

\section{Aims}

The study was conducted to evaluate the efficacy and safety of levetiracetam in migraine prophylaxis in young patients.

\section{Methods}

Ten consecutive patients aged $12-21$ years with typical or atypical migraine were reviewed prior to and following the administration of levetiracetam for 6 months (750-2250 mg/day).

\section{Results}

Headache score, duration, and frequency showed considerable improvement in all patients compared to baseline. Headaches were eliminated in 3 patients. Electroencephalogram showed dysrhythmia grade 2 or 3 at baseline, which improved to grade 1 in all patients following the treatment period.

\section{Conclusion}

In this pilot study, levetiracetam was effective and well tolerated. The improvements in headache outcomes in this group of patients may be due, in part, to the effect of levetiracetam on electroencephalogram dysrhythmias. These preliminary results of levetiracetam seem to be promising in relieving headaches in the pediatric age group.

No conflict of interest.

Published: 18 September 2014

doi:10.1186/1129-2377-15-S1-M9

Cite this article as: Rizk: EHMTI-0349. Levetiracetam in the treatment of pediatric headache. The Journal of Headache and Pain 2014 15(Suppl 1):M9.
Submit your manuscript to a SpringerOpen ${ }^{\circ}$ journal and benefit from:

- Convenient online submission

- Rigorous peer review

- Immediate publication on acceptance

- Open access: articles freely available online

- High visibility within the field

- Retaining the copyright to your article

Submit your next manuscript at $>$ springeropen.com
(C) 2014 Rizk; licensee Springer. This is an Open Access article distributed under the terms of the Creative Commons Attribution License (http://creativecommons.org/licenses/by/2.0), which permits unrestricted use, distribution, and reproduction in any medium, provided the original work is properly cited. 